\title{
Intralymphatic immunotherapy
}

\author{
Gabriela Senti ${ }^{1 *}$ and Thomas M Kündig ${ }^{2}$
}

\begin{abstract}
Gold Standard allergen-specific immunotherapy is associated with low efficacy because it requires either many subcutaneous injections of allergen or even more numerous sublingual allergen administrations to achieve amelioration of symptoms. Intralymphatic vaccination can maximize immunogenicity and hence efficacy. We and others have demonstrated that as few as three low dose intralymphatic allergen administrations are sufficient to effectively alleviate symptoms. Results of recent prospective and controlled trials suggest that this strategy may be an effective form of allergen immunotherapy.
\end{abstract}

Keywords: Administration routes, Allergen immunotherapy, Intralympathic, Vaccination

\section{Introduction}

Specific immunotherapy (SIT) is the only disease modifying therapy for IgE-mediated allergic diseases. Subcutaneous immunotherapy is still considered the gold standard. One of the more recent developments is intralymphatic immunotherapy.

Frey and Wenk proved in 1957 [1] with a series of elegant skin flap experiments that antigens need to reach lymph nodes via afferent lymph vessels to induce a Tcell response. More recently experiments in spleenless (Hox11-/-) and alymphoplastic (aly/aly) mutant mice have confirmed the importance of secondary lymphoid organs, or neo-lymphoid aggregates [2], for elicting immune responses [3].

Early in lymphocyte development T- and B cell receptors are randomly rearranged resulting in $\mathrm{T}$ and $\mathrm{B}$ cells carrying a diverse repertoire of receptors. While this provides the ability of specific recognition of all possible antigens, it also requires antigens to be presented to approximately $10^{7} \mathrm{~T}$ - and $\mathrm{B}$ cells before eliciting an immune response. Therefore, only antigens that are washed into secondary lymphoid organs, where exposure to high numbers of $\mathrm{T}$ and $\mathrm{B}$ cells can occur, will generate an immune response. Antigens, however, that bypass secondary lymphoid organs have a reduced likelihood to encounter specific $\mathrm{T}$ or $\mathrm{B}$ cells, and are thus largely ignored. The phenomenon is termed the "geographic concept of immunogenicity" [4-6].

\footnotetext{
* Correspondence: gabriela.senti@usz.ch

${ }^{1}$ Clinical Trials Center, University Hospital Zurich, Raemistrasse 100/MOU2,

$\mathrm{CH}-8091$ Zurich, Switzerland

Full list of author information is available at the end of the article
}

This concept remains valid although it may appear rather simplistic in the light of current understanding of immune regulation by dendritic cells and $\mathrm{T}$ cells. Being aware of the complexity of immune regulation we should none the less remember that the key trigger and regulator of the immune response is the antigen.

The lymph vessels role has evolved to drain pathogens into lymph nodes, thus enabling the immune system to generate an immune response at the earliest. Small particles of $20-200 \mathrm{~nm}$ size, i.e. the size of viruses, are quite efficiently drained in a free form from peripheral injection sites into lymph nodes. Usually, however, only a few percent of the injected particles reach the lymph nodes [7]. Larger particles in the size range 500-2000 $\mathrm{nm}$ are mostly carried into lymph nodes by DCs [7]. Nonparticulate antigens, however, are much less efficiently transported into lymph nodes. Only a very small fraction, i.e. between $10^{-3}$ and $10^{-6}$, of the injected doses arrive there. Many of today's vaccines and immunotherapeutic agents are non-particulate, therefore the injection directly into a lymph node should boost antigen presentation in the lymph node and thence improve the immune response.

\section{Review}

As early as in 1977 a first review on intralymphatic vaccination was published [8]. In the early 1970s Juillard et al. used this method to enhance tumor cell based cancer vaccines in dogs. Ten years later, researchers were looking for the most efficient route of immunization for producing antibodies against purified proteins which 
were available in only very small amounts. In the 1980s reports were published of nanogram quantities of protein eliciting immune responses when injected into lymph nodes $[9,10]$. Thereafter in various fields where conventional routes of administration produced insufficient results or where maximizing the immune response was the goal, such as in cancer vaccines, intralymphatic vaccination was performed.

Intralympatic vaccination has been shown to improve the efficacy of various vaccines, e.g.

- BCG vaccines in dogs [8] and mice [11].

- DC-based cancer vaccines [12-18],

- Immunostimulating complexes (ISCOMS) [19],

- MHC class I binding peptide vaccines [20,21],

- Naked DNA vaccines [21-27],

- Protein based vaccines for immunization of macaques against SIV [28-34],

- Protein based vaccines in cows [35],

- Tumor cell-based cancer vaccines [4,8,36-40],

- Vaccines in cats against feline immunodeficiency virus using a protein based vaccine [41],

Moreover, lymph node targeting can also enhance the efficacy of adjuvants. Intralymphatic administration of the adjuvant $\mathrm{CPG}$ required 100 times lower doses of antigen compared with subcutaneous administration. Lower doses avoid undesired systemic adverse effects of the adjuvant [42]. This is in line with reports of enhanced efficacy of CpG and a better safety profile when targeting particles to lymph nodes [43,44].

Biodistribution studies in mice revealed that after direct lymph-node injection 100-fold higher antigen doses reached the lymph nodes than after subcutaneous injection in the drained area of a lymph node [45]. Intralymphatic and subcutaneous injections of radiotraced proteins in humans gave similar results. A ${ }^{99 \mathrm{~m}} \mathrm{Tc}$-labeled protein was injected directly into a superficial inguinal lymph node on the right abdominal side. On the left side, the same dose was injected subcutaneously $10 \mathrm{~cm}$ above the inguinal lymph nodes. Figure 1 shows that only a small fraction of the subcutaneously administered protein had reached the lymph nodes after 4 hours, and that this fraction had not increased after 25 hours. In contrast, after intralymphatic injection the protein had drained into the deep subcutaneous lymph nodes and already after 20 minutes it was detected in a pelvic lymph node. Intralymphatic injection could efficiently pulse five lymph nodes with the full amount of the protein.

\section{Intralymphatic immunotherapy with allergen extracts}

IgE-mediated allergies, such as allergic rhino-conjunctivitis and asthma today affect up to $35 \%$ of the population in westernized countries [46-49]. Subcutaneous allergen-specific immunotherapy (SIT) is the gold standard treatment, i.e. the administration of gradually increasing quantities of an allergen [50-52] over years. The immunotherapy confers long term symptom improvement [53-56], but the 30-80 visits of a physician over 3-5 years compromizes patient compliance. SIT is also associated with frequent allergic side effects and with a risk of anaphylaxis and death [57-59].

Allergen immunotherapy induces a phenotype shift in the T-cell response from Th2 to Th1 $[60,61]$ and stimulates the generation of allergen-specific T-regulatory cells [60-62]. Serum titers of allergen-specific IgG antibodies, particularly IgG4, rise [63]. It is a matter of debate as to which of these immunological mediators is ultimately responsible for improving the allergic symptoms.

Intralymphatic administration of allergens to mice significantly enhanced the efficiency of immunization by inducing 10-20 times higher allergen-specific IgG2a antibody responses with as little as $0.1 \%$ of the allergen

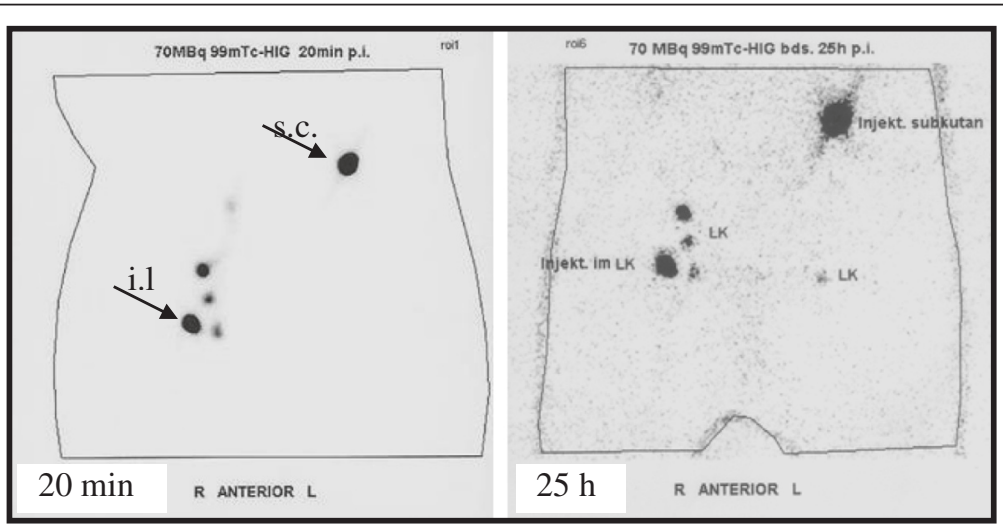

Figure 1 Biodistribution after intralymphatic administration. Biodistribution of 99mTc-labelled human lgG after intralymphatic (left abdominal side) and subcutaneous (right abdominal side) injections. Radio tracing was made by gamma-imaging 20 min (left panel) and 25 hours (right panel) after injection. Arrows indicate the site of injection (s.c., subcutaneous, i.l., intralymphatic). 
dose [45]. Intralymphatic injection of allergens also enhanced the secretion of IL-2, IL-4, IL-10 and IFN- $\gamma$ compared to subcutaneous injection. This may indicate that intralymphatic administration does not polarize the response to the allergen, but overall generates a stronger Th1, Th2, and T-regulatory response [45].

Four separate clinical trials of the authors' group have meanwhile demonstrated the feasibility, efficacy and safety of intralymphatic allergen immunotherapy. In the first clinical trial, eight patients allergic to bee-venom were given three low-dose injections of bee venom directly into their inguinal lymph nodes, whereas they would normally have received 70 subcutaneous injections. In this proof of concept trial seven of eight treated patients were protected against a subsequent bee sting challenge (Senti et al., manuscript in preparation). Similar results were achieved in a larger multi-center clinical trial with 66 bee venomallergic patients (Senti et al., manuscript in preparation). In an other randomized controlled clinical trial, 165 patients with grass pollen-induced hay fever were administered either 54 subcutaneous injections with high dose pollen extract within three years or three low-dose intralymphatic injections over eight weeks. The three low-dose intralymphatic allergen injections reduced treatment time from three years to eight weeks and enhanced safety and efficacy of the treatment [64]. The results based on questionnaires and by combining patients treated with one of two allergens/seasons (grass and birch pollen) have been independently confirmed in a double-blind placebocontrolled trial using intralymphatic administration with the same dose, immunization regimen and grass pollen extract, and with tree pollen extract [65]. One trial with intralymphatic administration of grass pollen extract, however, only detected immunological alterations without clinical efficacy [66]. In that trial the time interval between injections was reduced to 2 weeks, whereas in the successful trials $[64,65]$ the antigens were administered every 4 weeks. It is a well known fact of basic vaccine immunology that time intervals between injections of less than 4 weeks interferes with memory B cell formation and maturation of affinity $[67,68]$. Some authors, however, maintain that the time intervals argument is only valid for preventive vaccines, and that comparisons of low-power trials are strongly influenced by differences in endpoints and ways of assessment of clinical efficacy [69].

\section{Targeting intralymphatic vaccines to the MHC class II pathway}

As intralymphatic vaccination brings the antigen directly to the lymph node $\mathrm{DCs}$, the $\mathrm{CD} 4+\mathrm{T}$ cell response may be enhanced by intracellular translocation sequences and sequences further targeting the antigen to the $\mathrm{MHC}$ class II pathway. Such allergy vaccines can be targeted to MHC class II molecules located in the endoplasmatic reticulum by fusing allergens to a tat-translocation peptide derived from HIV and to a part of the invariant chain. Several experimental studies have shown that such targeting not only bypasses the inefficient pinocytosis process but also the enzymatic degradation in phagolysosomes. Both can significantly enhance immunogenicity $[45,70,71,72]$. A first clinical trial has already proved this concept in a double blinded placebo-controlled setup [73].

\section{Intralymphatic immunotherapy is not painful}

Subcutaneous lymph nodes are readily located by sonography since their paracortical area is hypoechoic (Figure 2). Injection into a superficial lymph node in the groin is usually performed in a few minutes and does not require great expertise in sonographic technique. What the patient feels during intralymphatic injection is solely the penetration of the skin, as lymph nodes carry few pain receptors. The pain of an intralymphatic injection thus is comparable with that of a subcutaneous injection. In the trials patients have rated intralymphatic injection less painful than venous puncture [64].

\section{Conclusions}

Clinical trials indicate intralymphatic immunotherapy to be not only efficient and safe, but also more convenient for the patient, as well as associated with a lower risk of systemic adverse effects, including anaphylaxis and lethal consequences. With as little as 3 injections within 12 weeks, a relief of symptoms can be achieved that is comparable to that obtained with standard subcutaneous immunotherapy necessitating up to 100 injections over 3 to 5 years. As

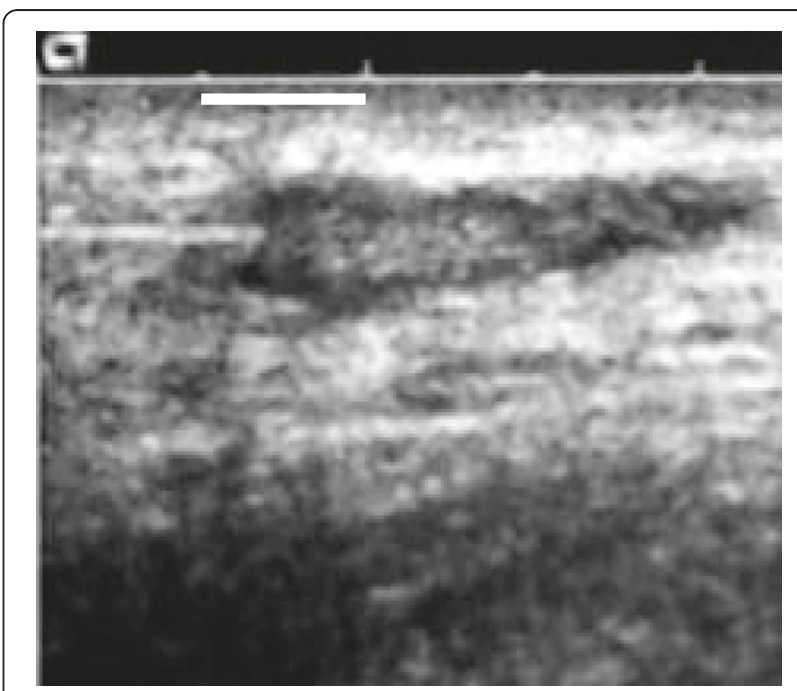

Figure 2 Intralymphatic injection. A sand blasted needle, being inserted into the lymph node from the right was used for better reflection and therefore visibility in the ultrasound. The dark, hypoechoic area represents the paracortex of the lymph node, which is approx. $15 \mathrm{~mm}$ long and $5 \mathrm{~mm}$ under the skin surface. 
clinical evidence so far is available for grass pollen and bee venom, more clinical trials are required to assess the clinical usefulness of intralymphatic immunotherapy for other common allergens.

\section{Consent}

Written informed consent was obtained from the patient for the publication of this report and any accompanying images.

\section{Abbreviations}

BCG: Bacillus calmette-guérin; CD4+: Cluster of differentiation 4; CpG: Dinucleotide cytosine-phosphate-guanine; DC: Dendritic cell; HIV: Human immunodeficiency virus; IFNY: Interferon gamma; IL-: Interleukin-; MHC: Major histocompatibility complex; SIT: Specific immunotherapy; SIV: Simian immunodeficiency virus.

\section{Competing interests}

The authors declare that they have no competing interests.

\section{Authors' contributions}

GS and TK contributed equally to the develoment of the manuscript. Both authors have reviewed and approved the final version.

\section{Acknowledgements}

Support for the dissemination of the WAO Immunotherapy and Biologics Online Monograph is provided by the following sponsors: Circassia, Boehringer-Ingleheim, and ORA Inc.

\section{Author details}

${ }^{1}$ Clinical Trials Center, University Hospital Zurich, Raemistrasse 100/MOU2, $\mathrm{CH}-8091$ Zurich, Switzerland. ${ }^{2}$ Department of Dermatology, University Hospital Zurich, Zurich, Switzerland.

\section{Received: 17 April 2014 Accepted: 14 November 2014}

Published online: 07 March 2015

\section{References}

1. Frey JR, Wenk P. Experimental studies on the pathogenesis of contact eczema in the guinea-pig. Int Arch Allergy Appl Immunol. 1957;11:81-100

2. Greter M, Hofmann J, Becher B. Neo-lymphoid aggregates in the adult liver can initiate potent cell-mediated immunity. PLoS Biol. 2009;7:e1000109.

3. Karrer U, Althage A, Odermatt B, Roberts CW, Korsmeyer SJ, Miyawaki S, et al. On the key role of secondary lymphoid organs in antiviral immune responses studied in alymphoplastic (aly/aly) and spleenless (Hox11(-)/-) mutant mice. J Exp Med. 1997;185:2157-70.

4. Kundig TM, Bachmann MF, DiPaolo C, Simard JJ, Battegay M, Lother H, et al, Fibroblasts as efficient antigen-presenting cells in lymphoid organs. Science. 1995:268:1343-7.

5. Zinkernagel RM, EhI S, Aichele P, Oehen S, Kundig T, Hengartner H. Antigen localisation regulates immune responses in a dose- and time-dependent fashion: a geographical view of immune reactivity. Immunol Rev. 1997;156:199-209.

6. Zinkernagel RM. Localization dose and time of antigens determine immune reactivity. Semin Immunol. 2000;12:163-71. discussion 257-344.

7. Manolova V, Flace A, Bauer M, Schwarz K, Saudan P, Bachmann MF. Nanoparticles target distinct dendritic cell populations according to their size. Eur J Immunol. 2008:38:1404-13.

8. Juillard GJ, Boyer PJ. Intralymphatic immunization: current status. Eur J Cancer. 1977:13:439-40.

9. Sigel MB, Sinha YN, VanderLaan WP. Production of antibodies by inoculation into lymph nodes. Methods Enzymol. 1983;93:3-12.

10. Nilsson BO, Svalander PC, Larsson A. Immunization of mice and rabbits by intrasplenic deposition of nanogram quantities of protein attached to Sepharose beads or nitrocellulose paper strips. J Immunol Methods. 1987;99:67-75

11. Waeckerle-Men Y, Bruffaerts N, Liang Y, Jurion F, Sander P, Kundig TM, et al. Lymph node targeting of BCG vaccines amplifies CD4 and CD8 T-cell responses and protection against Mycobacterium tuberculosis. Vaccine. 2013;31:1057-64
12. Lesimple T, Neidhard EM, Vignard V, Lefeuvre C, Adamski H, Labarriere $\mathrm{N}$, et al. Immunologic and clinical effects of injecting mature peptide-loaded dendritic cells by intralymphatic and intranodal routes in metastatic melanoma patients. Clin Cancer Res. 2006;12:7380-8.

13. Mackensen A, Krause T, Blum U, Uhrmeister P, Mertelsmann R, Lindemann A. Homing of intravenously and intralymphatically injected human dendritic cells generated in vitro from CD34+ hematopoietic progenitor cells. Cancer Immunol Immunother. 1999;48:118-22.

14. Grover A, Kim GJ, Lizee G, Tschoi M, Wang G, Wunderlich JR, et al. Intralymphatic dendritic cell vaccination induces tumor antigen-specific, skin-homing T lymphocytes. Clin Cancer Res. 2006;12:5801-8.

15. Brown K, Gao W, Alber S, Trichel A, Murphey-Corb M, Watkins SC, et al. Adenovirus-transduced dendritic cells injected into skin or lymph node prime potent simian immunodeficiency virus-specific $T$ cell immunity in monkeys. J Immunol. 2003;171:6875-82.

16. de Vries IJ, Lesterhuis WJ, Barentsz JO, Verdijk P, van Krieken JH, Boerman $\mathrm{OC}$, et al. Magnetic resonance tracking of dendritic cells in melanoma patients for monitoring of cellular therapy. Nat Biotechnol. 2005;23:1407-13.

17. De Vries IJ, Krooshoop DJ, Scharenborg NM, Lesterhuis WJ, Diepstra JH, Van Muijen GN, et al. Effective migration of antigen-pulsed dendritic cells to lymph nodes in melanoma patients is determined by their maturation state. Cancer Res. 2003;63:12-7.

18. Lesimple T, Moisan A, Carsin A, Ollivier I, Mousseau M, Meunier B, et al. Injection by various routes of melanoma antigen-associated macrophages: biodistribution and clinical effects. Cancer Immunol Immunother. 2003;52:438-44.

19. Koopman G, Bogers WM, van Gils M, Koornstra W, Barnett S, Morein B, et al. Comparison of intranasal with targeted lymph node immunization using PR8-Flu ISCOM adjuvanted HIV antigens in macaques. J Med Virol. 2007;79:474-82.

20. Johansen P, Haffner AC, Koch F, Zepter K, Erdmann I, Maloy K, et al. Direct intralymphatic injection of peptide vaccines enhances immunogenicity. Eur J Immunol. 2005;35:568-74.

21. Smith KA, Tam VL, Wong RM, Pagarigan RR, Meisenburg BL, Joea DK, et al. Enhancing DNA vaccination by sequential injection of lymph nodes with plasmid vectors and peptides. Vaccine. 2009;27:2603-15.

22. Maloy KJ, Erdmann I, Basch V, Sierro S, Kramps TA, Zinkernagel RM, et al. Intralymphatic immunization enhances DNA vaccination. Proc Natl Acad Sci U S A. 2001;98:3299-303.

23. Heinzerling L, Basch V, Maloy K, Johansen P, Senti G, Wuthrich B, et al. Critical role for DNA vaccination frequency in induction of antigen-specific cytotoxic responses. Vaccine. 2006;24:1389-94.

24. Weber J, Boswell W, Smith J, Hersh E, Snively J, Diaz M, et al. Phase 1 trial of intranodal injection of a Melan-A/MART-1 DNA plasmid vaccine in patients with stage IV melanoma. J Immunother. 2008;31:215-23.

25. Tagawa ST, Lee P, Snively J, Boswell W, Ounpraseuth S, Lee S, et al. Phase I study of intranodal delivery of a plasmid DNA vaccine for patients with Stage IV melanoma. Cancer. 2003;98:144-54.

26. Weber JS, Vogelzang NJ, Ernstoff MS, Goodman OB, Cranmer LD, Marshall JL, et al. A phase 1 study of a vaccine targeting preferentially expressed antigen in melanoma and prostate-specific membrane antigen in patients with advanced solid tumors. J Immunother. 2011;34:556-67.

27. Ribas A, Weber JS, Chmielowski B, Comin-Anduix B, Lu D, Douek M, et al. Intra-lymph node prime-boost vaccination against Melan $A$ and tyrosinase for the treatment of metastatic melanoma: results of a phase 1 clinical trial. Clin Cancer Res. 2011;17:2987-96.

28. Lehner T, Wang Y, Cranage M, Bergmeier LA, Mitchell E, Tao L, et al. Protective mucosal immunity elicited by targeted iliac lymph node immunization with a subunit SIV envelope and core vaccine in macaques. Nat Med. 1996;2:767-75.

29. Kawabata S, Miller CJ, Lehner T, Fujihashi K, Kubota M, McGhee JR, et al. Induction of Th2 cytokine expression for p27-specific IgA B-cell responses after targeted lymph node immunization with simian immunodeficiency virus in rhesus macaques. J Infect Dis. 1998;177:26-33.

30. Lehner T, Mitchell E, Bergmeier L, Singh M, Spallek R, Cranage M, et al. The role of gammadelta $T$ cells in generating antiviral factors and betachemokines in protection against mucosal simian immunodeficiency virus infection. Eur J Immunol. 2000;30:2245-56.

31. Bogers WM, Bergmeier LA, Ma J, Oostermeijer H, Wang Y, Kelly CG, et al. A novel HIV-CCR5 receptor vaccine strategy in the control of mucosal SIV/HIV infection. Aids. 2004;18:25-36.

32. Bogers WM, Bergmeier LA, Oostermeijer $H$, ten Haaft $P$, Wang $Y$, Kelly CG, et al. CCR5 targeted SIV vaccination strategy preventing or inhibiting SIV infection. Vaccine. 2004;22:2974-84. 
33. Klavinskis LS, Bergmeier LA, Gao L, Mitchell E, Ward RG, Layton G, et al. Mucosal or targeted lymph node immunization of macaques with a particulate SIVp27 protein elicits virus-specific CTL in the genito-rectal mucosa and draining lymph nodes. J Immunol. 1996;157:2521-7.

34. Lehner T, Bergmeier LA, Tao L, Panagiotidi C, Klavinskis LS, Hussain L, et al. Targeted lymph node immunization with simian immunodeficiency virus p27 antigen to elicit genital, rectal, and urinary immune responses in nonhuman primates. J Immunol. 1994;153:1858-68.

35. Guidry AJ, O'Brian CN, Oliver SP, Dowlen HH, Douglass LW. Effect of Whole Staphylococcus aureus and Mode of Immunization on Bovine Opsonizing Antibodies to Capsule. J Dairy Sci. 1994;77:2965-74.

36. Ochsenbein AF, Sierro S, Odermatt B, Pericin M, Karrer U, Hermans J, et al. Roles of tumour localization, second signals and cross priming in cytotoxic T-cell induction. Nature. 2001:411:1058-64.

37. Juillard GJ, Boyer PJ, Niewisch H, Hom M. Distribution and consequences of cell suspensions following intralymphatic infusion. Bull Cancer. 1979;66:217-28.

38. Juillard GJ, Boyer PJ, Snow HD. Intralymphatic infusion of autochthonous tumor cells in canine lymphoma. Int J Radiat Oncol Biol Phys. 1976;1:497-503.

39. Juillard GJ, Boyer PJ, Yamashiro CH. A phase I study of active specific intralymphatic immunotherapy (ASILI). Cancer. 1978;41:2215-25.

40. Juillard GJ, Boyer PJ, Yamashiro CH, Snow HD, Weisenburger TH, McCarthy T, et al. Regional intralymphatic infusion (ILI) of irradiated tumor cells with evidence of distant effects. Cancer. 1977;39:126-30.

41. Finerty S, Stokes CR, Gruffydd-Jones TJ, Hillman TJ, Barr FJ, Harbour DA. Targeted lymph node immunization can protect cats from a mucosal challenge with feline immunodeficiency virus. Vaccine. 2001;20:49-58.

42. von Beust BR, Johansen P, Smith KA, Bot A, Storni T, Kundig TM. Improving the therapeutic index of $\mathrm{CPG}$ oligodeoxynucleotides by intralymphatic administration. Eur J Immunol. 2005:35:1869-76.

43. Storni T, Ruedl C, Schwarz K, Schwendener RA, Renner WA, Bachmann MF. Nonmethylated CG motifs packaged into virus-like particles induce protective cytotoxic T cell responses in the absence of systemic side effects. J Immunol. 2004;172:1777-85.

44. Bourquin C, Anz D, Zwiorek K, Lanz AL, Fuchs S, Weigel S, et al. Targeting CpG oligonucleotides to the lymph node by nanoparticles elicits efficient antitumoral immunity. J Immunol. 2008;181:2990-8

45. Martinez-Gomez JM, Johansen P, Erdmann I, Senti G, Crameri R, Kundig TM Intralymphatic Injections as a New Administration Route for AllergenSpecific Immunotherapy. Int Arch Allergy Immunol. 2009;150:59-65.

46. Arbes Jr SJ, Gergen PJ, Elliott L, Zeldin DC. Prevalences of positive skin test responses to 10 common allergens in the US population: results from the third National Health and Nutrition Examination Survey. J Allergy Clin Immunol. 2005:116:377-83.

47. Verlato G, Corsico A, Villani S, Cerveri I, Migliore E, Accordini S, et al. Is the prevalence of adult asthma and allergic rhinitis still increasing? Results of an Italian study. J Allergy Clin Immunol. 2003;111:1232-8.

48. Worldwide variation in prevalence of symptoms of asthma, allergic rhinoconjunctivitis, and atopic eczema: ISAAC. Beasley R and the International Study of Asthma and Allergies in Childhood (ISAAC) Steering Committee. The International Study of Asthma and Allergies in Childhood (ISAAC) Steering Committee. Lancet. 1998;351:1225-1232.

49. Wuthrich B, Schindler C, Medici TC, Zellweger JP, Leuenberger P. IgE levels, atopy markers and hay fever in relation to age, sex and smoking status in a normal adult Swiss population. SAPALDIA (Swiss Study on Air Pollution and Lung Diseases in Adults) Team. Int Arch Allergy Immunol. 1996;111:396-402.

50. Bousquet J, Lockey R, Malling HJ. Allergen immunotherapy: therapeutic vaccines for allergic diseases. A WHO position paper. J Allergy Clin Immunol. 1998;102:558-62.

51. Lockey RF. "ARIA": global guidelines and new forms of allergen immunotherapy. J Allergy Clin Immunol. 2001;108:497-9.

52. Varney VA, Gaga M, Frew AJ, Aber VR, Kay AB, Durham SR. Usefulness of immunotherapy in patients with severe summer hay fever uncontrolled by antiallergic drugs. BMJ. 1991;302:265-9.

53. Durham SR, Walker SM, Varga EM, Jacobson MR, O'Brien F, Noble W, et al. Long-term clinical efficacy of grass-pollen immunotherapy. N Engl J Med. 1999;341:468-75.

54. Golden DB, Kwiterovich KA, Kagey-Sobotka A, Valentine MD, Lichtenstein LM. Discontinuing venom immunotherapy: outcome after five years. J Allergy Clin Immunol. 1996;97:579-87.

55. Pajno GB, Barberio G, De Luca F, Morabito L, Parmiani S. Prevention of new sensitizations in asthmatic children monosensitized to house dust mite by specific immunotherapy. A six-year follow-up study. Clin Exp Allergy. 2001:31:1392-7.

56. Moller C, Dreborg S, Ferdousi HA, Halken S, Host A, Jacobsen L, et al. Pollen immunotherapy reduces the development of asthma in children with seasonal rhinoconjunctivitis (the PAT-study). J Allergy Clin Immunol. 2002;109:251-6

57. Lockey RF, Benedict LM, Turkeltaub PC, Bukantz SC. Fatalities from immunotherapy (IT) and skin testing (ST). J Allergy Clin Immunol. 1987;79:660-77.

58. Lockey RF, Turkeltaub PC, Olive ES, Hubbard JM, Baird-Warren IA, Bukantz SC. The Hymenoptera venom study. III: Safety of venom immunotherapy. J Allergy Clin Immunol. 1990;86:775-80.

59. Stewart 2nd GE, Lockey RF. Systemic reactions from allergen immunotherapy. J Allergy Clin Immunol. 1992;90:567-78.

60. Till SJ, Francis JN, Nouri-Aria K, Durham SR. Mechanisms of immunotherapy. J Allergy Clin Immunol. 2004;113:1025-34. quiz 1035.

61. Norman PS. Immunotherapy: 1999-2004. J Allergy Clin Immunol. 2004;113:1013-23. quiz 1024.

62. Vissers JL, van Esch BC, Hofman GA, Kapsenberg ML, Weller FR, van Oosterhout AJ. Allergen immunotherapy induces a suppressive memory response mediated by IL-10 in a mouse asthma model. J Allergy Clin Immunol. 2004;113:1204-10.

63. Pierson-Mullany LK, Jackola D, Blumenthal M, Rosenberg A. Altered allergen binding capacities of Amb a 1-specific lgE and lgG4 from ragweed-sensitive patients receiving immunotherapy. Ann Allergy Asthma Immunol. 2000:84:241-3.

64. Senti G, Prinz Vavricka BM, Erdmann I, Diaz MI, Markus R, McCormack SJ, et al. Intralymphatic allergen administration renders specific immunotherapy faster and safer: a randomized controlled trial. Proc Natl Acad Sci U S A. 2008;105:17908-12.

65. Hylander T, Latif L, Petersson-Westin U, Cardell LO. Intralymphatic allergenspecific immunotherapy: an effective and safe alternative treatment route for pollen-induced allergic rhinitis. J Allergy Clin Immunol. 2013;131:412-20.

66. Witten M, Malling HJ, Blom L, Poulsen BC, Poulsen LK. Is intralymphatic immunotherapy ready for clinical use in patients with grass pollen allergy? J Allergy Clin Immunol. 2013;132:1248-52. e1245.

67. Kundig TM, Johansen P, Bachmann MF, Cardell LO, Senti G. Intralymphatic immunotherapy: Time interval between injections is essential. J Allergy Clin Immunol. 2014;133:930-1.

68. Siegrist CA. Vaccine Immunology. In Vaccines, 6th Edition. Edited by Plotkin SA: Elsevier; Saunders, Philadelphia 2013: 14-32

69. Malling HJ, Witten M, Poulsen LK. Intralymphatic immunotherapy: Time interval between injections is essential Reply. J Allergy Clin Immun. 2014;133:931-2

70. Martinez-Gomez JM, Johansen P, Rose H, Steiner M, Senti G, Rhyner C, et al. Targeting the $\mathrm{MHC}$ class II pathway of antigen presentation enhances immunogenicity and safety of allergen immunotherapy. Allergy. 2009;64:172-8.

71. Rhyner C, Kundig T, Akdis CA, Crameri R. Targeting the MHC II presentation pathway in allergy vaccine development. Biochem Soc Trans. 2007:35:833-4.

72. Crameri R, Fluckiger S, Daigle I, Kundig T, Rhyner C. Design, engineering and in vitro evaluation of MHC class-II targeting allergy vaccines. Allergy. 2007:62:197-206

73. Senti G, Crameri R, Kuster D, Johansen P, Martinez-Gomez JM, Graf N, et al. Intralymphatic immunotherapy for cat allergy induces tolerance after only 3 injections. J Allergy Clin Immunol. 2012;129:1290-6.

\section{Submit your next manuscript to BioMed Central and take full advantage of:}

- Convenient online submission

- Thorough peer review

- No space constraints or color figure charges

- Immediate publication on acceptance

- Inclusion in PubMed, CAS, Scopus and Google Scholar

- Research which is freely available for redistribution 